\title{
15-lecie Wydziału Studiów Międzynarodowych i Politologicznych i Instytutu Studiów Politologicznych Uniwersytetu Lódzkiego
}

Wydział Studiów Międzynarodowych i Politologicznych Uniwersytetu Łódzkiego powstał w roku 2000. Specyfika prowadzonych na wydziale badań polega na ich interdyscyplinarności oraz internacjonalizacji. Obecnie funkcję dziekana WSMiP pełni prof. Tomasz Domański. W ramach wydziału prowadzone są studia na następujących kierunkach: międzynarodowe studia kulturowe, politologia, stosunki międzynarodowe. Wydział uczestniczy również w prowadzeniu międzywydziałowych indywidualnych studiów humanistycznych oraz interdyscyplinarnych studiów doktoranckich. W ramach WSMiP działają dwa instytuty: Instytut Studiów Międzynarodowych oraz Instytut Studiów Politologicznych.

Instytut Studiów Politologicznych (ISP) został utworzony w 2000 r. i jest wiodącą, wyspecjalizowaną placówką politologiczną w regionie łódzkim, kształci studentów i doktorantów, prowadzi badania w dziedzinach współczesnych systemów politycznych, teorii polityki, myśli politycznej i prognozowania, polityki zagranicznej i bezpieczeństwa międzynarodowego oraz stosunków regionalnych i globalnych.

W skład ISP wchodzą obecnie trzy jednostki: Katedra Systemów Politycznych (kierownik prof. Alicja Stępień-Kuczyńska), Katedra Teorii Polityki i Myśli Politycznej (kierownik prof. Eugeniusz Ponczek), Katedra Teorii Polityki Zagranicznej i Bezpieczeństwa (kierownik dr hab. prof. UŁ Robert Łoś). W latach 2000-2008 dyrektorem ISP był prof. dr hab. Eugeniusz Ponczek, obecnie jest nim prof. dr hab. Alicja Stępień-Kuczyńska.

Kierunek politologia na Wydziale Studiów Międzynarodowych i Politologicznych realizowany jest od roku akademickiego 2007/2008. Wcześniej (od roku 2001/2002) funkcjonował jako specjalność nauki polityczne na kierunku stosunki międzynarodowe. W tym okresie wykształcił ponad 600 politologów. Oferuje specjalności na poziomie licencjatu (bezpieczeństwo międzynarodowe, polityka i zarządzanie w strukturach lokalnych, kultura polityczna i polityka historyczna) i na poziomie magisterium (bezpieczeństwo państwa, doradztwo i zarządzanie polityczne, diagnozowanie i prognozowanie polityczne, Political Management). 
Przyjęty na Wydziale model kształcenia interdyscyplinarnego pozwala na kształtowanie otwartej na nowe możliwości ścieżki kariery, a umiędzynarodowienie Wydziału daje o sobie znać na przykładzie realizacji od roku akademickiego 2013/2014 programu Mobility Direct.

Od początku swojego istnienia w ISP przykłada się dużą wagę do nawiązywania i utrzymywania współpracy z krajowymi i międzynarodowymi ośrodkami politologicznymi. Na poziomie Instytutu Studiów Politologicznych zawarto umowy z uczelniami zagranicznymi z: Białorusi, Niemiec, Słowacji, Szwecji, Ukrainy

W okresie 15 lat działalności ISP pracownicy i doktoranci opublikowali blisko 200 monografii i monografii zbiorowych, około 1000 artykułów naukowych w czasopismach politologicznych ogólnopolskich i zagranicznych oraz rozdziałów w monografiach zbiorowych. Zorganizowano szereg konferencji międzynarodowych i krajowych, spośród których należy wymienić: cykl konferencji Dialog europejski Zachód-Wschód, Mity polityczne - wyobrażenia zbiorowe - polityka historyczna, a także 20 lat transformacji w regionie Europy Środkowej $i$ Wschodniej; Sąsiedztwo i pogranicze. Od konfliktu w przeszłości do wspótpracy w przyszłości; Bezpieczeństwo Polski w ramach NATO; Konsekwencje rozpadu ZSRR - aspekt międzynarodowy $i$ wewnętrzny.

Z inicjatywy politologów od 2001 r. działa Łódzki Oddział Polskiego Towarzystwa Nauk Politycznych z siedzibą w ISP. Instytut jest również organizatorem olimpiady przedmiotowej dla licealistów z wiedzy o Polsce i świecie współczesnym. W ISP od 2002 r. działa Koło Naukowe Politologów KNP, przekształcone w koło naukowe studentów i doktorantów. Podstawowym celem jego działalności jest rozwijanie wiedzy studentów w zakresie nauk politycznych oraz nawiązywanie współpracy z ośrodkami politologicznymi w całym kraju. Od roku 2012 istnieje Koło Naukowe Expressis Verbis, które zajmuje się organizacją spotkań z przedstawicielami świata polityki, biznesu, publicystyki i nauki. Pracownicy ISP są reprezentowani we władzach ZG PTNP, ŁTN, Komitecie Nauk Politycznych PAN, Komisji Badań Integracji Europy PAN Oddział w Łodzi, Polskiej Komisji Akredytacyjnej, licznych radach programowych czasopism polskich i zagranicznych. 


\section{5-летие Факультета Международных отношений и политологии и Института Политологических исследований Лодзинского университета}

Факультет международных отношений и политологии Лодзинского Университета был создан в 2000 году. Спецификой проводимых на факультете исследований является их междисциплинарность, а также их интернациональность. Деканом факультета в настоящее время является профессор Томаш Доманьски. В рамках факультета осуществляется обучение по следующим специальностям: Политология, Международные отношения, Международная культурология. Факультет принимает также участие в реализации Межфакультетской индивидуальной гуманитарной специальности, а также Междисциплинарной аспирантской специальности. В состав факультета входят два института: Институт международных исследований и Институт политологических исследований.

Институт политологических исследований (ИПИ) был создан в 2000 году и является ведущим, специализированным политологическим центром в Лодзинском регионе, обучающим студентов и аспирантов, осуществляющим исследования в области современных политических систем, теории политики, политической мысли и прогнозирования, внешней политики и международной безопасности, региональных и глобальных отношений.

В состав ИПИ в настоящее время входят три кафедры: Кафедра политических систем (руководитель профессор Алиция Стемпень-Кучинска), Кафедра теории политики и политической мысли (руководитель профессор Евгениуш Поньчэк), Кафедра теории внешней политики и безопасности (руководитель профессор Роберт Лось). В 2000-2008 гг. Директором ИПИ был профессор Евгениуш Поньчэк, а в настоящее время им является профессор Алиция Стемпень-Кучинская.

Специальность Политология на Факультете международных отношений и политологии реализуется с 2007/2008 учебного года. Ранее (начиная с 2001/2002 учебного года) функционировала как специализация политические науки на специальности международные отношения. За этот период выпущено более 600 политологов.

Специальность политология предлагает обучение бакалавров (по следующим направлениям: международная безопасность, политика и управление 
в структурах местного самоуправления, политическая культура и историческая политика) и магистров (направления: безопасность государства, политическое управление и консультирование, политическое прогнозирование и диагностирование, Political Management). Принятая на нашем факультете модель междисциплинарного обучения позволяет создать открытый на новые возможности карьерный путь, а международный характер факультета подтверждается реализацией, начиная с 2013/2014 учебного года, таких программ как Mobility Direct.

С начала своего существования ИПИ уделяет большое внимание установлению и поддержанию сотрудничества с польскими и международными политологическими центрами. До настоящего момента на уровне Института политологических исследований заключены договоры с иностранными вузами из Беларуси, Германии, Словакии, Швеции, Украины.

За время функционирования ИПИ работники и аспиранты института опубликовали около 200 авторских и коллективных монографий, около 1000 научных статей в общепольских и иностранных политологических журналах, а также разделов коллективных монографий. Организован ряд международных и национальных конференций, среди которых следует отметить: цикл конференций Политические мифы - коллективное мышление - историческая политика; 20 лет трансформации в регионе Центральной и Восточной Европы; Соседство и приграничье. От конфликта в прошлом к сотрудничеству в будущем; Безопасность Польши в рядах НАТО; Последствия распада СССР - внутренний и внешний аспекты.

С 2001 года по инициативе политологов функционирует Лодзинское отделение Польского общества политических наук с центром в ИПИ.

Институт политологических исследований является также организатором олимпиад для лицеистов в области знаний о Польше и современном мире, а также знаний о Европейском Союзе, которые проходят на окружном уровне.

В Институте с 2002 года функционирует Научный кружок политологов, преобразованный в научный кружок для студентов и аспирантов. Основной целью деятельности кружка является развитие знаний в области политических наук среди студентов, а также развитие сотрудничества с политологическими центрами по всей стране. С 2012 года функционирует научный кружок Expressis Verbis, который занимается организацией встреч с представителями мира политики, бизнеса, публицистики и науки.

Работники ИПИ представлены в руководстве Главного управления Польского научного товарищества политологов, Лодзинского научного товарищества, Комитете политических наук Польской академии наук, Комиссии исследования интеграции Европы Лодзинского отделения Польской академии наук, Польской аккредитационной комиссии, многочисленных программных советах польских и иностранных научных изданий.

Thumaczenie Andrzej Lulkowski 


\section{The 15th anniversary of the Faculty of International and Political Studies and the Institute of Political Studies}

Its research activities are interdisciplinary and conducted in broad international cooperation. The faculty has B.A. and M.A. programs in Political Science, International Relations and International Cultural Studies. They are composed of a range of courses from the area of humanities and social sciences, including political science, marketing and management. The head of the faculty is prof. Tomasz Domański.

The Institute of Political Studies, one of the two institutes in the structure of the faculty, was established in 2000. Its research areas include comparative politics, political theory, political philosophy, political forecasting, international politics and security, global and regional relations. It consists of three units: Department of Political Systems (chair: prof. Alicja Stępień-Kuczyńska), Department of Theory of Foreign Politics and Security (chair: dr. hab. prof. UŁ Robert Łoś), Department of Political Theory and Political Thought (chair: dr. hab. prof. UŁ Andrzej Sepkowski). The director of the institute is prof. Alicja Stępień-Kuczyńska; in 2000-2008 the function was held by prof. Eugeniusz Ponczek.

B.A and M.A. in Political Science is offered at the Faculty since academic year 2007/2008. It is regarded as an attractive choice for students, opening many interesting paths of academic and professional career.

The Institute of Political Studies has always sought international cooperation, both in research and academic exchange of staff and students. The Institute's international partners include: Belarusian State University in Minsk, Chernivtsi National University, Ukraine, The Friendship of Nations University of Russia, Moscow State Social University, Tula State University, Russia, The Siberian Institute of International Relations and Regional Studies, Russia and Lomonosov State University in Moscow (Faculty of Political Science). The Institute's staff members, including prof. Alicja Stępień-Kuczyńska, dr Katarzyna Dośpiał-Borysiak, dr Maciej Potz and dr Agata Włodarska have conducted research and guest lectures abroad (in Russia, USA, Norway, Finland, Spain, Germany etc.). 
In May 2012 International Centre for Eastern European Research was inaugurated (chair - prof. Alicja Stępień-Kuczyńska, secretary - dr. Michał Słowikowski). The idea behind the Centre is to integrate the research and organizational activity of various units of the University of Łódź pertaining to the, broadly defined, Eastern European studies, and especially focusing on Russia, Ukraine, Belarus and Moldova. Among the Centre's principal activities is publishing the Eastern Review journal and organizing international scientific conferences, such as: The region of Eastern Europe and the global social, political, economic and cultural processes, Eastern Europe and the challenge of modernization, Contemporary Ukraine: towards modern statehood, Eastern Europe in the $21^{\text {st }}$ century. Poland-Ukraine: the partnership of regions (2014). Prof. Stępien-Kuczyńska is also the chair of the Łódź division (est. 2001) of Polish Political Science Association and vice-president of the whole association.

The Institute holds regular seminars for academic staff and $\mathrm{PhD}$ students, as well as a cycle of Political Science Debates, with the participation of distinguished scholars and other guests from around the country. Talented students can participate in Young Political Scientists group. The Institute also organizes political science competition for secondary school students.

Tłumaczenie Maciej Potz 